\title{
Assessment of toxic metals in commonly used herbs and spices in Turkey
}

\author{
Hakan Özden ${ }^{1}$ (D) \\ 'İstanbul University, Faculty of Science, Department of Biology, Division of Botany, İstanbul, Turkey
}

ORCID IDs of the authors: H.Ö. 0000-0001-8693-9884

Cite this article as: Ozden, H. (2021). Assessment of toxic metals in commonly used herbs and spices in Turkey. İstanbul Journal of Pharmacy, 51 (3), 392-397.

\begin{abstract}
Background and Aims: The levels of cadmium $(\mathrm{Cd})$ and lead $(\mathrm{Pb})$ were analyzed in frequently used herbs including ginger, liquorice, nutmeg and turmeric in Turkey.

Materials and Methods: The levels of $\mathrm{Cd}$ and $\mathrm{Pb}$ in commonly used herbs were analyzed by inductively coupled plasma optical emission spectrometry after a closed microwave-assisted digestion.

Results: The concentration ranges for the $\mathrm{Cd}$ and $\mathrm{Pb}$ were found to be $0.25-0.78 \mathrm{mg} / \mathrm{kg}$ and $3.04-6.45 \mathrm{mg} / \mathrm{kg}$, respectively. While $\mathrm{Pb}$ levels were below the maximum permissible limits, high $\mathrm{Cd}$ levels were detected in herbs which would not pose any health risk for consumers regarding an exposure assessment.

Conclusion: It is important to implement regular monitoring of heavy metal content in herbs, including medicinal plants, to assess their potential risks to human health in consideration of the potential for multiple exposure via other sources.

Keywords: Cadmium, lead, ginger, liquorice, nutmeg, turmeric
\end{abstract}

\section{INTRODUCTION}

Herbs are commonly used as flavoring agents, spices, and confectionery additives in the food industry. Moreover, their use as remedies in traditional medicine has increased dramatically worldwide. Thus, a critical evaluation of the safety and quality of herbs and herbal products is important for health authorities (WHO, 2007). It is well known that herbs may be contaminated by natural and chemical contaminants, including pesticides and heavy metals, which may be harmful to consumers (WHO, 2007). In addition to the natural existence in water and soil, the common sources of heavy metal pollution in the environment are anthropogenic activities such as industrial production processes, household waste and waste materials (Järup, 2003). Heavy metals are considered to be significant potential hazards to human, animal and plant health due to their widespread presence, toxicity and persistence in the environment (Järup, 2003). The accumulation of heavy metals in the harvestable parts of plants occurs by root uptake, foliar absorption, and decomposition of specific compounds (Haider, Naithani, \& Barthwal, 2004; Kishan, Bhattacharya, \& Sharma, 2014; Sarma, Deka, \& Deka, 2011). While heavy metals such as copper, iron, zinc, and manganese play an essential role in the structural and biochemical function of the plants, toxic heavy metals such as lead (Pb) cadmium (Cd), mercury and arsenic can cause harmful effects in plants (Nagajyoti, Lee, \& Sreekanth, 2010). In addition, an accumulation of toxic heavy metals in plants could also cause adverse effects for consumers (WHO, 2007).

$\mathrm{Cd}$ and $\mathrm{Pb}$ are two of the major heavy metals that are biologically non-essential and exhibit toxicity, according to health authorities (WHO, 2007, WHO 2011, EFSA 2011). Pb causes significant alterations in various biological processes including cell adhesion, intra- and inter-cellular signaling, apoptosis, ionic transportation, enzyme regulation, calcium homeostasis and oxidative stress re-

Address for Correspondence:

Hakan ÖZDEN, e-mail: ozdenh@istanbul.edu.tr

This work is licensed under a Creative Commons Attribution 4.0 International License. 
sulting in toxic effects (Jaishankar, Tseten, Anbalagan, Mathew, \& Beeregowda, 2014). Cd binds to metallothionein, cysteinerich protein, which is accumulated in the renal tissue causing nephrotoxicity (Jaishankar et al., 2014). Available data indicates cause for concern regarding these heavy metals because they are known human carcinogens (Järup, 2003). On the basis of occupational studies, Cd has been classified as a human carcinogen-group 1 (IARC, 1993) and inorganic Pb has been classified as probably carcinogenic to humans-group 2A (IARC, 2006) by the International Agency for Research on Cancer. The World Health Organization (WHO) established the maximum permissible limits for $\mathrm{Cd}$ and $\mathrm{Pb}$ as $0.3 \mathrm{mg} / \mathrm{kg}$ and $10 \mathrm{mg} / \mathrm{kg}$ in herbal materials, respectively (WHO, 2007).

Different parts of plants are rich in phytochemicals and antioxidants and have been used as food commodities, medicinal plant, and dietary supplement. Liquorice, roots and extracts of Glycyrrhizia glabra L., have been commonly used as medicinal plant, dietary supplement and food commodities. It has been shown to be beneficial in the treatment of respiratory diseases, gastrointestinal diseases, endocrine disorders, skin diseases, immunodeficiency and cancer (Karahan, Avsar, Ozyigit, \& Berber, 2016; Sharma, Katiyar, \& Agrawal, 2018). Ginger, the root of Zingiber officinale, has been widely used as a food condiment and dietary supplement all over the world due its high content of minerals, vitamins, and phytochemicals. Ginger has been used in medicine as anti-microbial, anti-pyretic, analgesic, anti-inflammatory, hypoglycaemic, anti-ulcer, anti-emetic, anti-hypertensive, hypolipidemic effects (Shahrajabian, Sun \& Cheng, 2019). Nutmeg, the dried seed kernel of Myristica Fragrans, has been used as spice which exhibits many pharmacological activities such as anti-inflammatory, analgesic, antioxidant, antibacterial, antidiabetic and anticancer activities (Ha, Vu, Tran, Kim, Woo, \& Min, 2020). Turmeric, the rhizome of Curcuma longa, has been used as a spice and medical herb due to its antioxidant, anti-inflammatory, antimutagenic, antimicrobial, and anticancer properties (Hewlings, \& Kalman, 2017)

In order to avoid toxicity in humans, it is important to monitor the levels of toxic metals present in every step of the food chain (Jeong et al., 2012). Up to now, there have been a number of studies on the heavy metal contamination levels of herbal materials, including herbal medicines in Turkey (Başgel \& Erdemoğlu, 2006; Bilgic Alkaya, Karaderi, Erdoğan, \& Kurt Cücü, 2015; Karahan, Ozyigit, Saracoglu, Yalcin, Ozyigit \& Ilcim, 2020; Leblebici, Bahtiyar, \& Ozyurt, 2012; Ozcan, 2004; Ozcan, Ünver, Uçar, \& Arslan, 2008; Ozcan \& Akbulut, 2007;
Ozturk, Altay, \& Karahan, 2017; Ozyigit et al., 2018; Sekeroglu, Ozkutlu, Kara, \& Ozguven, 2008; Tercan, Ayanoglu, \& Bahadirli, 2016; Görür, Keser, Akçay, Dizman, \& Okumuşoğlu, 2011; Divrikli, Horzum, Soylak, \& Elci, 2006; Ozkutlu, Sekeroglu, \& Kara, 2006; Ozden \& Ozden, 2018; Tokalıoğlu, 2012). In the previous study, it was reported that $\mathrm{Cd}$ and $\mathrm{Pb}$ were found in the range of $0.324-0.524 \mathrm{mg} / \mathrm{kg}$ and $3.123-6.487 \mathrm{mg} / \mathrm{kg}$, respectively, in linden, chamomile and sage teas (Ozden \& Ozden, 2018). The aims of the present study were (i) to determine levels of $\mathrm{Cd}$ and $\mathrm{Pb}$ in frequently used herbs including ginger, liquorice, nutmeg, and turmeric (ii) to evaluate their potential hazards to human health.

\section{MATERIAL AND METHODS}

\section{Reagents}

Standard solutions of $1000 \mu \mathrm{g} / \mathrm{mL}$ of $\mathrm{Cd}$ and $\mathrm{Pb}$ in nitric acid were obtained from Merck (Darmstadt, Germany). Nitric acid (65\%) was purchased from Merck (Darmstadt, Germany). All of the reagents used were of analytical grade.

\section{Sample collection}

A total of 54 herbs including liquorice, ginger, turmeric, and nutmeg samples were randomly collected from local markets in İstanbul and the botanical identification was carried out by Hakan Ozden. Scientific name and the part of the plant used were shown in Table 1.

\section{Sample preparation}

Each herb sample was milled using a Waring Blender (Conair Corp., Stamford, CT, USA) and stored in clean polyethylene packages at $2-8^{\circ} \mathrm{C}$ until analysis. The digestion and extraction processes of $\mathrm{Pb}$ and $\mathrm{Cd}$ were carried out using a closed microwave system (Berghof MWS-4 device, Berghof instruments, Eningen, Germany) equipped with Teflon containers. 0.1-0.3 g of dried and homogenized herbs were placed in the Teflon containers and wet-digested at $150-190^{\circ} \mathrm{C}$ with $8 \mathrm{~mL}$ of $65 \%$ nitric acid. After cooling down to room temperature, the suspensions were diluted to $25 \mathrm{~mL}$ with deionized water. Blanks were also prepared using the same method. The samples were passed through syringe-type filters (Chromafil PET-45/25, Macheerey Nagel, Düren, Germany), then analyzed by ICP-OES instrument.

\section{ICP-OES analysis}

Analyses of $\mathrm{Cd}$ and $\mathrm{Pb}$ were conducted in herb samples using the inductively coupled plasma optical emission spectrometry (ICP-OES, Pelkin Elmer, Waltham, MA, USA) with optima 7000

Table 1. Classification of herb samples by scientific name and used part.

\begin{tabular}{|llll|}
\hline Common name & Scientific name & Used part & No. of samples analyzed \\
\hline Ginger & Zingiber officinale & Dried rhizome & 15 \\
Liquorice & Glycyrrhizia glabra L. & Dried root & 12 \\
Nutmeg & Myristica fragrans & Dried seed kernel & 12 \\
Turmeric & Curcuma longa & Dried rhizome & 15 \\
\hline
\end{tabular}


Table 2. Contamination of heavy metals in the analyzed herbs.

\begin{tabular}{|c|c|c|c|c|}
\hline \multirow{2}{*}{ Herbs } & \multirow{2}{*}{ No. of samples } & \multirow{2}{*}{ Positive (\%)a } & \multicolumn{2}{|c|}{ Mean of contamination $(\mathrm{mg} / \mathrm{kg}) \pm \mathrm{SD}^{*}$} \\
\hline & & & Cd & $\mathrm{Pb}$ \\
\hline Ginger & 15 & $15(100)$ & $0.43 \pm 0.09$ & $5.46 \pm 0.92$ \\
\hline Liquorice & 12 & $9(75)$ & $0.34 \pm 0.07$ & $3.51 \pm 0.38$ \\
\hline Nutmeg & 12 & $9(75)$ & $0.51 \pm 0.07$ & $4.25 \pm 0.72$ \\
\hline Turmeric & 15 & $14(93.33)$ & $0.67 \pm 0.08$ & $5.64 \pm 0.81$ \\
\hline Totally & 54 & $47(87.04)$ & $0.47 \pm 0.13$ & $4.89 \pm 1.09$ \\
\hline
\end{tabular}

DV model. The specifications of the instrument were as follows: RF generator power $1.3 \mathrm{~kW}$, gas flow rate $0.2 \mathrm{~L} / \mathrm{min}$ and nebulizer flow rate $0.8 \mathrm{~L} / \mathrm{min}$. The emission wavelengths were 226 $\mathrm{nm}$ for $\mathrm{Cd}$ and $220 \mathrm{~nm}$ for $\mathrm{Pb}$.

\section{Calibration procedure}

To assess the linearity of the method, calibration curves were prepared at six different concentrations $(0.25-5 \mathrm{mg} / \mathrm{L}$ for $\mathrm{Cd}$ and $0.4-10 \mathrm{mg} / \mathrm{L}$ for $\mathrm{Pb}$ ) and each injected in triplicates. Blanks were also used during the analysis to check for any possible contamination. For the sensitivity of method, limit of detections (LOD; signal-to noise ratio $=3$ ) and limit of quantifications $(\mathrm{LOQ}$; signal-to-noise ratio $=10$ ) were calculated for $\mathrm{Cd}$ and $\mathrm{Pb}$ in each of the matrixes. Recovery studies were performed utilizing certified reference materials and were done in triplicate.

\section{RESULTS}

\section{Method validation}

$\mathrm{Cd}$ and $\mathrm{Pb}$ recoveries were in the range of $86-104 \%$ with a relative standard deviation of 2.15-4.8\%. A good linear relationship was observed with correlation coefficients of 0.999 for $C d$ (with calibration equation of $y=0.9326 x-0.053$ ) and 0.9986 for $\mathrm{Pb}$ (with calibration equation of $y=0.9625 x-0.0079$ ). The levels of LOD and LOQ in herbs were $0.08 \mathrm{mg} / \mathrm{kg}$ and $0.25 \mathrm{mg} / \mathrm{kg}$ for $\mathrm{Cd}$ and 0.13 and $0.4 \mathrm{mg} / \mathrm{kg}$ for $\mathrm{Pb}$, respectively.

\section{$\mathbf{P b}$ and $\mathbf{C d}$ levels in herbs}

In total we analyzed 54 herbs, including liquorice (12), ginger (15), turmeric (15) and nutmeg (12) from unpackaged samples collected from local markets in İstanbul (Table 1). As shown in Table 2, 9 out of 12 liquorice, 15 out of 15 ginger, 14 out of 15 turmeric and 9 out of 12 nutmeg samples contained both $\mathrm{Cd}$ and $\mathrm{Pb}$ in the ranges of $0.25-0.78 \mathrm{mg} / \mathrm{kg}$ and $3.04-6.45 \mathrm{mg} / \mathrm{kg}$, respectively. Among the $\mathrm{Cd}$-positive samples, only one $\mathrm{li}$ quorice $(0.25 \mathrm{mg} / \mathrm{kg})$ and one ginger $(0.25 \mathrm{mg} / \mathrm{kg})$ sample $\mathrm{did}$ not exceed the maximum permissible level of Cd $(0.3 \mathrm{mg} / \mathrm{kg}$ ) set by WHO for herbal products (WHO, 2007), whereas 45 out of 54 herbs contained $\mathrm{Cd}$ above the maximum permissible level. In addition, the Pb levels in herbs were lower than the maximum permissible level $(10 \mathrm{mg} / \mathrm{kg}$ ) set by $\mathrm{WHO}$ (WHO, 2007). We also observed that all positive samples contained both $\mathrm{Cd}$ and $\mathrm{Pb}$.

\section{DISCUSSION}

The levels of $\mathrm{Pb}$ and $\mathrm{Cd}$ were investigated in 54 herb samples. The LOD levels were observed as 0.08 for $\mathrm{Cd}$ and 0.13 for $\mathrm{Pb}$ by ICP-OES analysis. Alhusban, Ata, \& Shraim (2019) reported that the LOD levels for $\mathrm{Cd}$ and $\mathrm{Pb}$ were 0.15 and $0.10 \mathrm{mg} / \mathrm{kg}$, respectively by ICP-OES which are similar for $\mathrm{Pb}$ and higher for Cd compared with our results.

As shown in Table 2, 47 out of 54 herbs contained $\mathrm{Cd}$ and $\mathrm{Pb}$ in the ranges of $0.25-0.78 \mathrm{mg} / \mathrm{kg}$ and $3.04-6.45 \mathrm{mg} / \mathrm{kg}$, respectively. Consistently, in a study from Turkey, the rhizomes of Glycyrrhiza glabra contained $\mathrm{Cd}$ and $\mathrm{Pb}$ at 0.4 and $7.725 \mathrm{mg} / \mathrm{kg}$, respectively (Karahan et al., 2020). In India, Kumar et al. showed that nutmeg contained $\mathrm{Cd}$ at $0.46 \mathrm{mg} / \mathrm{kg}$ and $\mathrm{Pb}$ at $30.07 \mathrm{mg} / \mathrm{kg}$, implicating risks associated with the ingestion of herbal medicines contaminated with high levels of Pb (Kumar et al., 2018). Siriangkhawut, Sittichan, Ponhong, \& Chantiratikul (2017) reported different levels of $\mathrm{Cd}$ and $\mathrm{Pb}$ found in medicinal plants, but they did not detect any in turmeric samples in Thailand. In Pakistan, Idrees et al. (2018) and Alhusban et al. (2019) showed $\mathrm{Pb}$ at levels of $4.48 \mathrm{mg} / \mathrm{kg}$ and $3.74 \mathrm{mg} / \mathrm{kg}$, respectively, in ginger samples, which are similar to the present results. Gasser et al. also reported $\mathrm{Cd}$ and $\mathrm{Pb}$ in the concentration ranges of $<0.07-0.64$ and $<0.4-4.12$ in ginger samples, $<0.07-0.18$ and $<0.4-1.45$ in liquorice samples and $<0.07-0.21$ and $<0.4-0.8$ in turmeric samples, respectively (Gasser, Klier Kuhn, \& Steinhoff, 2009). In a study from North Carolina, Pb was found in the range of 0.7-1.6 in ginger and $0.1-740 \mathrm{mg} / \mathrm{kg}$ in turmeric samples (Angelon-Gaetz, Klaus, Chaudhry, \& Bean, 2018). In Saudi Arabia, $\mathrm{Pb}$ was found at a rate of $1 \mathrm{mg} / \mathrm{kg}$ while $\mathrm{Cd}$ was not detected in turmeric samples (Seddigi, Kandhro, Shah, Danish, \& Soylak, 2016). In a study reported in Latvia, Reinholds, Pugajeva, Bavrins, Kuckovska, \& Bartkevics (2017) showed that mean levels of $\mathrm{Cd}$ and $\mathrm{Pb}$ were 0.04 and $0.13 \mathrm{mg} / \mathrm{kg}$ in nutmeg samples, respectively. In Italy, Bua et al. reported detecting $\mathrm{Cd}$ in the range of $0.033-0.294 \mathrm{mg} / \mathrm{kg}$ in nutmeg and $0.029-0.092 \mathrm{mg} / \mathrm{kg}$ in ginger, while $\mathrm{Pb}$ was found in the range of $0.164-1.402 \mathrm{mg} / \mathrm{kg}$ in nutmeg and $0.309-1.154 \mathrm{mg} / \mathrm{kg}$ in ginger samples (Bua, Annuario, Albergamo, Cicero, \& Dugo, 2016). In a study from Ethiopia, Baye \& Hymete (2010) showed $\mathrm{Cd}$ and $\mathrm{Pb}$ at mean levels of 0.34-0.42 $\mathrm{mg} / \mathrm{kg}$ and 0.17-0.25 $\mathrm{mg} / \mathrm{kg}$ in ginger samples, respectively, from three different places of collection. In a study from Malaysia, $\mathrm{Cd}$ and $\mathrm{Pb}$ were 
found at mean levels of $1.08 \mathrm{mg} / \mathrm{kg}$ and $5.54 \mathrm{mg} / \mathrm{kg}$ in turmeric and $1.97 \mathrm{mg} / \mathrm{kg}$ and $3.15 \mathrm{mg} / \mathrm{kg}$ in ginger samples, respectively (Nordin \& Selamat, 2013). In Zambia, high levels of $\mathrm{Pb}$ and $\mathrm{Cd}$ were found at the mean levels of $26.85 \mathrm{mg} / \mathrm{kg}$ and $2.39 \mathrm{mg} / \mathrm{mg}$ in ginger samples, respectively (Alolga, Chavez, \& Muyaba, 2018). Olujimi et al. (2017) did not detect Pb or $\mathrm{Cd}$ in ginger samples in Nigeria. In Iran, commercial powder and root samples of turmeric were positive for $\mathrm{Cd}$ content $(0.11-1.15 \mathrm{mg} / \mathrm{kg}$ ) and were positive for $\mathrm{Pb}$ content (0.11-0.62 mg/kg) (Ahmed, Khaleeq, Huma, \& Munir, 2017). $\mathrm{Pb}$ and $\mathrm{Cd}$ were detected at the levels of $0.093 \mathrm{mg} / \mathrm{kg}$ and $0.059 \mathrm{mg} / \mathrm{kg}$ in turmeric and $0.039 \mathrm{mg} / \mathrm{kg}$ and $0.105 \mathrm{mg} / \mathrm{kg}$ in nutmeg, respectively in the Republic of Korea (Shim, Cho, Leem, Cho, \& Lee, 2019).

Limited studies have been conducted regarding heavy metal contamination of herbal materials in Turkey (Başgel \& Erdemoğlu, 2006; Bilgic et al., 2015; Leblebici et al., 2012; Ozcan, 2004; Özcan et al., 2008; Ozcan \& Akbulut, 2007; Ozyigit et al., 2018; Sekeroglu et al., 2008; Tercan et al., 2016; Görür et al., 2011; Divrikli et al., 2006; Ozkutlu et al., 2006; Ozden \& Ozden, 2018; Tokalığlu, 2012). Among these, only a few studies reported on the heavy metal contamination of turmeric, ginger, nutmeg, and liquorice. Ozkutlu et al. (2006) reported Cd at the mean levels of $0.029 \mathrm{mg} / \mathrm{kg}$ in turmeric and $0.072 \mathrm{mg} / \mathrm{kg}$ in ginger, while $\mathrm{Cd}$ was not detected in nutmeg samples. Studies from Ozcan \& Akbulut (2007) and Sekeroglu, Ozkutlu, Kara, \& Ozguven (2008) found $\mathrm{Cd}$ at mean levels of $0.72 \mathrm{mg} / \mathrm{kg}$ and $0.043 \mathrm{mg} / \mathrm{kg}$ in liquorice, respectively. In another study, Pb was detected at a mean concentration of $3.01 \mathrm{mg} / \mathrm{kg}$ in ginger samples Tokalıoğlu (2012). In general, our data found levels of Cd and Pb in herbs very similar to the values reported in the literature from Turkey and elsewhere. It has been implied that variations in metal accumulation may be a result of differences in species, harvesting times, soil properties, locations and geographic conditions (Özcan et al., 2008; Kumar et al., 2018; Arpadjan, Celik, Taskesen, \& Gucen, 2008). As shown in the studies above conducted worldwide, it has been observed that very different levels of $\mathrm{Cd}$ and $\mathrm{Pb}$ levels are detected in herbs. It is concluded that the result may be due to different geographic locations, agricultural input (fertilizer and pesticides) and industrial activities.

A tolerable weekly intake of $\mathrm{Cd}$ of $2.5 \mu \mathrm{g} / \mathrm{kg}$ bw was established by the European Food Safety Authority (EFSA) (EFSA, 2011). In the present study, the weekly intake of $\mathrm{Cd}(\mu \mathrm{g} / \mathrm{kg} \mathrm{bw}$ ) was calculated according to our results because the tested herbals contained $\mathrm{Cd}$ levels exceeding those proposed by $\mathrm{WHO}(\mathrm{WHO}, 2007)$. It is considered a mean daily consumption of $2.3 \mathrm{~g}$ of herbal teas for the Middle Eastern diet (WHO, GEMS/ Food Regional Diets) for an adult with a mean body weight of $70 \mathrm{~kg}$ (WHO, 2003). In the present study, we found the maximum Cd level to be $0.78 \mathrm{mg} / \mathrm{kg}$ in the turmeric sample, which gives us the highest estimated human weekly intake for $\mathrm{Cd}$ as $0.18 \mu \mathrm{g} / \mathrm{kg}$. Thus, the intake of Cd represents $7.2 \%$ of the tolerable weekly intake set by EFSA (EFSA, 2011) which did not represent a risk to human health. Exposure assessment of $\mathrm{Cd}$ from the consumption of herbs (such as turmeric) used in tea was estimated for the first time for the Turkish population. Considering the different exposure sources, it is thought that it is important to monitor heavy metals in herbal products.

\section{CONCLUSION}

In summary, $\mathrm{Cd}$ and $\mathrm{Pb}$ were detected in the range of $0.25-$ $0.78 \mathrm{mg} / \mathrm{kg}$ and $3.04-6.45 \mathrm{mg} / \mathrm{kg}$ in herbs, respectively. We revealed that $\mathrm{Cd}$ levels in herbals exceeded the permissible limits, whereas $\mathrm{Pb}$ levels fell under the limit recommended by $\mathrm{WHO}(\mathrm{WHO}, 2007)$. According to the exposure assessment for $\mathrm{Cd}$, the intake of herbs does not represent a risk to human health. However, taking herbs together with other foods contaminated with heavy metals may cause adverse health effects resulting from the accumulative effects of heavy metals. Considering the different factors in geographical conditions and industrial activities, metal levels in herbs should be carefully monitored. In conclusion, regular monitoring of herbal materials, including medicinal plants sold in local markets as well as imported products, is necessary, as is continued consideration of the risks of heavy metal contamination.

Peer-review: Externally peer-reviewed.

Conflict of Interest: The authors have no conflict of interest to declare.

Financial Disclosure: Authors declared no financial support.

\section{REFERENCES}

- $\quad$ Ahmed, M., Khaleeq, A., Huma, R., Munir, S. (2017). Atomic absorption and inductively coupled plasma-optical emission spectroscopic method for determination of micronutrients and toxic metals in Curcuma longa L. to characterize human health toxicity. Spectroscopy Letters, 50(8), 432-439.

- $\quad$ Alhusban, A. A., Ata, S. A, Shraim, S. A. (2019). The safety assessment of toxic metals in commonly used pharmaceutical herbal products and traditional herbs for infants in Jordanian market. Biological Trace Element Research, 187(1), 307-315.

- $\quad$ Alolga, R. N., Chavez, M. A., Muyaba, M. (2018). Untargeted UPLCQ/TOF-MS-based metabolomics and inductively coupled plasma optical emission spectroscopic analysis reveal differences in the quality of ginger from two provinces in Zambia. Journal of Pharmacy and Pharmacology, 70(9), 1262-1271.

Angelon-Gaetz, K. A., Klaus, C., Chaudhry E. A., Bean, D. K. (2018). Lead in Spices, Herbal Remedies, and Ceremonial Powders Sampled from Home Investigations for Children with Elevated Blood Lead Levels-North Carolina, 2011-2018. Morbidity and Mortality Weekly Report, 67(46), 1290-1294.

Arpadjan, S., Celik, G., Taskesen, S., Gucen, S. (2008). Arsenic, cadmium and lead in medicinal herbs and their fractionation. Food and Chemical Toxicology, 46, 2871-2875.

- $\quad$ Başgel, S., Erdemoğlu, S. B. (2006). Determination of mineral and trace elements in some medicinal herbs and their infusions consumed in Turkey. Science of the Total Environment, 359(1-3), 82-89.

- $\quad$ Baye, H., Hymete, A. (2010). Lead and cadmium accumulation in medicinal plants collected from environmentally different sites. Bulletin of Environmental Contamination and Toxicology, 84(2), 197-201.

- Bilgic Alkaya, D., Karaderi, S,. Erdoğan, G., Kurt Cücü, A. (2015). İstanbul aktarlarında satılan bitkisel çaylarda ağir metal tayini. Marmara Pharmaceutical Journal, 19(2), 136-140.

- Bua, D. G., Annuario, G., Albergamo, A., Cicero, N., Dugo, G. (2016). Heavy metals in aromatic spices by inductively coupled plasmamass spectrometry. Food Additives and Contaminants: Part B, 9(3), 210-216. 
- Divrikli, U., Horzum, N., Soylak, M, Elci, L. (2006). Trace heavy metal contents of some spices and herbal plants from western Anatolia, Turkey. International Journal of Food Science and Technology, 41(6), 712-716.

- $\quad$ European Food Safety Authority (EFSA). (2011). Statement on tolerable weekly intake for cadmium. EFSA Journal, 9(2),1975.

- Gasser, U., Klier Kuhn, A. V., Steinhoff, B. (2009). Current findings on the heavy metal content in herbal drugs. Pharmeur Scientitific Notes, 1, 37-49.

- Görür, F. K., Keser, R., Akçay, N., Dizman, S., Okumuşoğlu, N. T. (2011). Radionuclides and heavy metals concentrations in Turkish market tea. Food Control, 22(12), 2065-2070.

- Ha, M. T., Vu, N. K., Tran, T. H., Kim, J. A., Woo, M. H., \& Min, B. S. (2020). Phytochemical and pharmacological properties of Myristica fragrans Houtt.: an updated review. Archives of Pharmacal Research, 43(11), 1067-1092.

- Haider, S., Naithani, V., Barthwal, J. (2004). Heavy metal content in some therapeutically important medicinal plants. Bulletin of Environmental Contamination and Toxicology, 72(1), 119-127.

- Hewlings, S. J., \& Kalman, D. S. (2017). Curcumin: a review of its effects on human health. Foods, 6(10), 92.

- Idrees, M., Rafiq, S., Ullah, S., Jan, F. A., Khan, M. N., Mabood, F. (2018). Heavy Metals Level of Medicinal Plants Collected From Selected District In Khyber-Pakthtunkhwa, Pakistan. Farmacia, 66(5), 861-865.

- International Agency for Research on Cancer (IARC). (1993). Monographs on the Evaluation of Carcinogenic Risks to Humans. Cadmium and cadmium compounds. In, Beryllium, Cadmium, Mercury and Exposure in the Glass Manufacturing Industry. Lyon: International Agency for Research on Cancer, 58, 119-237.

- International Agency for Research on Cancer (IARC). (2006). Monographs on the Evaluation of Carcinogenic Risks to Humans. Inorganic and Organic Lead Compounds. Lyon: International Agency for Research on Cancer, 87.

- Jaishankar, M., Tseten, T., Anbalagan, N., Mathew, B. B., \& Beeregowda, K. N. (2014). Toxicity, mechanism and health effects of some heavy metals. Interdisciplinary toxicology, 7(2), 60-72.

- Järup, L. (2003). Hazards of heavy metal contamination. British Medical Bulletin, 68(1), 167-182.

- Jeong, T. Y., Park, B. K., Cho, J. H., Kim, Y. I., Ahn, Y. C., Son, C. G. (2012). A prospective study on the safety of herbal medicines, used alone or with conventional medicines. Journal of Ethnopharmacology, 143, 884-888.

- Karahan, F., Avsar, C., Ozyigit, I. I., \& Berber, I. (2016). Antimicrobial and antioxidant activities of medicinal plant Glycyrrhiza glabra var. glandulifera from different habitats. Biotechnology \& Biotechnological Equipment, 30(4), 797-804.

- Karahan, F., Ozyigit, I. I., Saracoglu, I. A., Yalcin, I. E., Ozyigit, A. H., \& Ilcim, A. (2020). Heavy metal levels and mineral nutrient status in different parts of various medicinal plants collected from eastern Mediterranean region of Turkey. Biological Trace Element Research, 197(1), 316-329.

- $\quad$ Kishan, P. S., Bhattacharya, S., Sharma, P. (2014). American-Eurasian assessment of heavy metal contents of some Indian medicinal plants. Journal of Agriculture and Environmental Sciences, 14(10), 1125-1129.

- Kumar, N., Kulsoom, M., Shukla, V., Kumar, D., Kumar, S., Tiwari, J., Dwivedi, N. (2018). Profiling of heavy metal and pesticide residues in medicinal plants. Environmental Science and Pollution Research, 25(29), 29505-29510.

- Leblebici, S., Bahtiyar, S. D., Ozyurt, M. S. (2012). Kütahya aktarlarında satılan bazi tibbi bitkilerin ağır metal miktarlarının incelenmesi. Journal of Science and Technology of Dumlupınar University, 29, 1-6.
Nagajyoti, P. C., Lee, K. D., \& Sreekanth, T. V. M. (2010). Heavy metals, occurrence and toxicity for plants: a review. Environmental chemistry letters, 8(3), 199-216.

Nordin, N., Selamat, J. (2013). Heavy metals in spices and herbs from wholesale markets in Malaysia. Food Additives and Contaminants: Part B, 6(1), 36-41.

- Olujimi, O. O., Onifade, O. N., Towolawi, A. T., Akinhanmi, T. F., Afolabi, A. A., Olanite, K. A. (2017). Phyto-metals screening of selected anti-diabetic herbs and infused concoctions. Asian Pacific Journal of Tropical Biomedicine, 7(10), 909-914.

Ozcan, M. (2004). Mineral contents of some plants used as condiments in Turkey. Food Chemistry, 84(3), 437-440.

Ozcan, M. M., Akbulut, M. (2007). Estimation of Minerals, Nitrate and Nitrite Contents of Medicinal and Aromatic Plants Used as Spices, Condiments and Herbal Tea. Food Chemisrty, 106(2), 852858.

Özcan, M. M., Ünver, A., Uçar, T., Arslan, D. (2008). Mineral content of some herbs and herbal teas by infusion and decoction. Food Chemistry, 106(3), 1120-1127.

Ozden, H., Ozden, S. (2018). Levels of Heavy Metals and Ochratoxin A in Medicinal Plants Commercialized in Turkey. Turkish Journal of Pharmaceutical Sciences, 15(3), 376-381.

Ozkutlu, F., Sekeroglu, N., Kara, S. M. (2006). Monitoring of cadmium and micronutrients in spices commonly consumed in Turkey. Research Journal of Agriculture and Biological Sciences, 2(5), 223-226.

Ozturk, M., Altay, V., \& Karahan, F. (2017). Studies on trace elements distributed in Glycyrrhiza taxa in Hatay-Turkey. International Journal of Plant and Environment, 3(02), 01-07.

- Ozyigit, I. I., Yalcin, B., Turan, S., Saracoglu, A., Karadeniz, S., Yalcin, I. E., Demir, G. (2018). Investigation of heavy metal level and mineral nutrient status in widely used medicinal plants' leaves in Turkey: Insights into health implications. Biological Trace Element Research, 182(2), 387-406.

Reinholds, I,. Pugajeva, I., Bavrins, K., Kuckovska, G., Bartkevics, V. (2017). Mycotoxins, pesticides and toxic metals in commercial spices and herbs. Food Additives and Contaminants, Part B, 10(1), 5-14.

Sarma, H., Deka, S., Deka, H. (2011). Accumulation of heavy metals in selected medicinal plants. Reviews of Environmental Contamination and Toxicology, 214, 63-86.

Seddigi, Z. S., Kandhro, G. A., Shah, F., Danish, E., Soylak, M. (2016). Assessment of metal contents in spices and herbs from Saudi Arabia. Toxicology and Industrial Health, 32(2), 260-269.

Sekeroglu, N., Ozkutlu, F., Kara, S. M., Ozguven, M. (2008). Determination of cadmium and selected micronutrients in commonly used and traded medicinal plants in Turkey. Journal of the Science of Food and Agriculture, 88, 86-90.

Shahrajabian, M. H., Sun, W., Cheng, Q. (2019). Clinical aspects and health benefits of ginger (Zingiber officinale) in both traditional Chinese medicine and modern industry. Acta agriculturae scandinavica, section b-Soil \& Plant Science, 69(6), 546-556.

- Sharma, V., Katiyar, A., Agrawal, R. C. (2018). Glycyrrhiza glabra: chemistry and pharmacological activity. Sweeteners, 87.

Shim, J., Cho, T., Leem, D., Cho, Y., Lee, C. (2019). Heavy metals in spices commonly consumed in Republic of Korea. Food Additives and Contaminants, Part B, 12(1), 52-58.

Siriangkhawut, W., Sittichan, P., Ponhong, K., Chantiratikul, P. (2017). Quality assessment of trace $\mathrm{Cd}$ and Pb contaminants in Thai herbal medicines using ultrasound-assisted digestion prior to flame atomic absorption spectrometry. Journal of Food and Drug Analysis, 25(4), 960-967.

Tercan, H. S., Ayanoglu, F., Bahadirli, N. P. (2016). Determination of Heavy Metal Contents and Some Basic Aspects of Widely Used Herbal Teas in Turkey. Revista de Chimie, 67(5), 1019-1022. 
- Tokalıoğlu, ş. (2012). Determination of trace elements in commonly consumed medicinal herbs by ICP-MS and multivariate analysis. Food Chemistry, 134(4), 2504-2508.

- World Health Organization (WHO). (2003). GEMS/Food regional diets, regional per capita consumption of raw and semi-processed agricultural commodities / prepared by the Global Environment Monitoring System/Food Contamination Monitoring and Assessment Programme (GEMS/Food), Rev. ed. World Health Organization, ISBN: 9241591080.
- World Health Organization (WHO). (2007). Department of Technical Cooperation for Essential Drugs and Traditional Medicine. World Health Organization Guidelines for Assessing Quality of Herbal Medicines with Reference to Contaminants and Residues Geneva Switzerland, ISBN: 9789241594448.

- World Health Organization (WHO). (2011). Safety evaluation of certain food additives and contaminants. Lead. WHO Food Addıtives Series, 64, 381-497. 